\title{
Bargaining Power in the European Council
}

\author{
Jonas Tallberg \\ Stockholm University \\ jonas.tallberg@statsvet.su.se
}

What resources grant heads of state and government influence in the European Council? Despite its political importance, the European Council has only been subject to limited research. Part of the explanation is the difficulties of conducting research on a political body that convenes behind closed doors, whose proceedings are undocumented, and whose participants are unusually hard to gain access to. This paper reports the results of a project designed to overcome the problems of previous research through a unique series of elite interviews with European heads of state and government. Drawing on general theories of negotiation, it isolates and illustrates three complementary sources of bargaining power in the European Council: state sources of power, institutional sources of power, and individual sources of power. Elite testimonies suggest that the state dimension of power is most fundamental, whereas the institutional and individual dimensions of power play a secondary role and mainly mediate the impact of structural power asymmetries.

Paper presented at the Tenth Biennial EUSA Conference, Montreal, May 17-19, 2007 
The European Council constitutes the supreme political body in the European Union. Occupying a position at the apex of the EU's institutional system, the European Council provides strategic guidelines for the development of the EU, serves as the ultimate decisionmaker on issues too complex or contentious for the Council of Ministers to handle, shapes the EU’s collective foreign policy, coordinates member state policy on socioeconomic issues, appoints the senior officials of the EU institutions, initiates and concludes intergovernmental conferences that amend the treaties, and effectively decides if, when, and how the EU should welcome new members.

Yet, despite its central political importance, the European Council has only been subject to limited research, most of which is dated, atheoretical, and limited in empirical scope. Part of the explanation is the difficulties of conducting research on a political body that convenes behind closed doors, whose proceedings are undocumented, and whose participants are unusually hard to gain access to. More specifically, existing research may be divided into three categories. The first consists of a set of monographs on the European Council, dating from the second half of the 1980s and the first half of the 1990s (Bulmer and Wessels 1987; Donat 1987; Werts 1992; Taulègne 1993; Johnston 1994). The strength of these works is the description of the European Council's early development and influence. Yet they make few or no attempts to draw on general theories in political science, and they offer no guidance on developments beyond the early 1990s. The second category consists of individual chapters on the European Council in volumes on the Council of Ministers or the EU institutions generally (Westlake and Galloway 2004, ch. 9; Hayes-Renshaw and Wallace 2006, ch. 6; Schoutheete 2006). These chapters provide insightful up-to-date overviews of the European Council, but cannot address the politically interesting aspects of this institution in any depth. The third category is composed of think-tank reports that either address the potential reform of the European Council (e.g., Grant 2002; Schoutheete and Wallace 2002), or provide accounts of 
individual meetings (e.g., Ludlow 2002, 2004). These offer refreshing perspectives on the European Council and useful chronologies of negotiations, but do not qualify as theory-driven research.

This paper explores the sources of bargaining power in the European Council. What resources grant national executives influence in summit negotiations? Why are some heads of government more influential than others? Ultimately, it is question of explaining the outcomes of European Council negotiations. The paper moves beyond existing research in three central respects. First, it addresses negotiation dynamics inside the European Council, which so far have not been subject to systematic research. Second, it draws explicitly on general theories of negotiation and decision-making in isolating, explicating, and categorizing alternative sources of bargaining power. Third, it synthesizes and presents a unique set of elite testimonies on bargaining power in the European Council.

Prevailing conceptions of power in the European Council are often either overly legalistic or prone to simplistic power distinctions. Formally speaking, all heads of state and government enjoy equal status in the European Council as a product of the principle of unanimity. The executives of Luxembourg and Malta have the same right to veto proposals as the executives of Germany and France. However, even cursory knowledge of European affairs suggests that formal authority is one thing, and influence over political outcomes another. Yet, when the legalistic perspective is surrendered for power-sensitive interpretations, these tend to present general claims about differences between large and small member states, without specifying how differences in size matter, and without recognizing alternative sources of bargaining power. As Andrew Moravcsik notes: "Intergovernmental explanations often speak of Germany, France, or Britain as 'powerful' or 'influential' in negotiations, but such claims are rarely demonstrated by specifying what resources convey 'power' or which outcomes demonstrate that one country has been influential” $(1998,53)$. 
The general argument of this paper is that bargaining power in the European Council can be captured in three dimensions: state sources of power, institutional sources of power, and individual sources of power. Bargaining power is defined here as the capacity of the national executive to achieve a distributional outcome that as closely as possible reflects the preferences of the member state he or she represents. The first dimension of bargaining power is the most fundamental. On most issues, differences between the member states in structural power resources - economic strength, population size, military capabilities, political stability, and administrative capacity - decisively shape bargaining outcomes. Yet differences in state sources of power do not provide the full picture. The dominance of Europe's resourceful states is mediated, and sometimes even offset, by the other two dimensions of bargaining power. Institutional features of the European Council - the access to the veto and the rotating Presidency - constitute additional sources of bargaining power, as do the personal qualities of the chief executives as negotiators - their personal authority and their level of expertise. Coalition-building, in this context, is conceived of as a strategy for pooling bargaining power, rather than an independent source of power itself.

The paper reports the results of a project specifically designed to overcome the problems associated with previous research on the European Council. The core strategy is an ambitious and unique series of elite interviews with acting or former presidents, prime ministers, and foreign ministers, as well as top-level officials of member states and EU institutions. ${ }^{1}$ The list of interviewees includes thirteen heads of state or government and ministers of foreign affairs, most of which have held office in the period from the mid-1990 and onwards. In principle, the interviewees appeared on record, but were granted anonymity where this was specifically requested, often because of relations to third countries.

\footnotetext{
${ }^{1}$ A complete list of interviewees is provided in the appendix.
} 
While offering unique empirical insights, elite interviewing is associated with risks that should be acknowledged and preferably minimized. Skewed samples may affect the conclusions from the interview material. Retired politicians or civil servants may suffer from a selective and self-aggrandizing memory. Active politicians and civil servants may be tempted to tailor their answers to suit specific political objectives. I pursue a fourfold strategy for dealing with these problems and minimizing the risk of biases in the conclusions. First, interviewees have been selected to control for known political divides in EU politics, notably left-right, large-small, north-south, and intergovernmentalist-federalist. Second, I have asked principled questions about experiences of bargaining power in the European Council, rather than questions about specific historical events. Third, I have centered on general tendencies in the interview material, based on multiple interviews, and I only draw on individual interviews when exemplifying general tendencies through quotes. Fourth, I report suspected biases, such as when interviewees speak in their own favor.

I lay out the argument in three sections. The first section explains how bargaining power may be derived from a member state's aggregate structural power, as well as from its issue-specific power. In the second section, I specify how the institutional context of European Council negotiations generates additional sources of bargaining power. The third section specifies individual attributes that heads of government may profit from to varying degrees. The paper ends with a conclusion that outlines the implications of this argument for research on EU politics and international bargaining generally.

\section{State sources of power}


Heads of government in the European Council represent a diverse set of member states. How and to what extent do differences between member states affect the bargaining power of their national executives, in negotiations with other heads of government in the European Council? Drawing on the international relations (IR) literature on state power, I distinguish in this section between a member state's aggregate structural power and its issue-specific power, where the first refers to the overall capabilities of a state and the latter to its resources in a particular policy area. The testimonies from European Council participants suggest that both forms of state power loom large in summit bargaining. Despite the fact that cooperation in the EU is more institutionalized than in any other international organization, and takes place between a relatively homogenous group of industrialized democracies, differences in state capabilities and resources are perceived to matter greatly.

\section{Aggregate structural power}

Aggregate structural power refers to a state's total amount of resources and capabilitie - its territory, population, economic strength, military capabilities, technological development, political stability, and administrative capacity. The notion that a state's power is a reflection of its aggregate resources harks back to the age of great power conflict in Europe, but it also features in the modern analysis of world politics, where it constitutes a key component of realist theory (Morgenthau 1948; Waltz 1979). State capabilities, in this view, determine national power, which in turn determines the position of a state in relation to other states in the international system. The emphasis on aggregate resources signals the central assumption that capabilities can be added up, are measureable, and in theory can be calculated into a national power score. 
When applied to the analysis of international negotiations, this perspective suggests that states of greater aggregate structural power will prevail, since they can use their superior resources to coax and cajole weaker parties into submission through threats and promises (Hampson with Hart 1995, 8-11; Hopmann 1998, 99-111). The outcomes of international negotiations are likely to represent the interests of the most powerful states. The process of international negotiations is thus of limited importance, since outcomes in any case will reflect the distribution of structural power between states. Negotiation tactics and strategies only constitute a "transmission belt," through which resources and capabilities are translated into instruments of power in interstate bargaining.

European Council participants unanimously testify that differences in aggregate structural power matter significantly in this forum. Former French president Valéry Giscard d'Estaing speaks of how French and German dominance in the European Council during his time in office was only normal, since these two countries originally constituted the majority in every conceivable way - territory, population, and GDP. Hubert Védrine, former French minister of foreign affairs, echoes this perspective: "What grants influence in the European Council is first and foremost the actual power of the country. We do, after all, live in the real world. Germany obviously has more power than, say, Malta and Luxembourg. --- A member state's actual power is decided by its economy, demography, geography, political system, and diplomatic reach.” Yet also representatives of small states testify to the impact of structural power resources. As Jean-Claude Juncker, long-serving prime minister of Luxembourg, states: “Greater member states have a greater say. We never admit it, of course, but one has to acknowledge that geography and demography are playing a role.” Jean-Claude Piris, director general of the Council’s Legal Service, is even more blunt: “The most important factor explaining bargaining power is state size - citizens and GDP.” 
The notion of aggregate structural resources suggests that a state's potential for influence will only be as large as the sum of its multiple capabilities. In the context of European Council negotiations, this helps to explain a frequently noted anomaly as regards the influence of large member states. Often mentioned is the inability of Italy to translate its potential power, grounded in structured resources, into political influence in the European Council. Despite a population and an economic strength at the level of France, Britain, and Germany before unification, Italy is broadly seen as having suffered in European Council negotiations from the instability of its domestic political system. As one foreign minister states: “Italy has many of the general advantages - economy, demography, geography, founding state, etc. - but one important weakness in its political system: instability.” Another long-term participant, representing a small member state, offers a similar reflection, limiting the category of influential large states to France, Germany, and Britain: “Today, Italy sometimes appears at the margin of a dossier. Italy is not one of the four great member states. Spain is trying to replace Italy, but it is not successful, and Poland will have to admit that it is not part of these great member states, although being Poland.”

Yet how, exactly, do differences in aggregate structural power impact on European Council negotiations? In the age of great power rivalry, aggregate structural resources allowed the strong to back up negotiation demands with threats of military aggression or economic isolation. In Europe of today, gun-boat diplomacy is not an option and aggregate structural power affects negotiations in considerably more subtle ways. The interviews suggest that resources and capabilities rarely are actively deployed in the bargaining process. Rather, asymmetries in aggregate structural power matter indirectly, by affecting a state’s range of alternatives, the resources it can commit to an issue, the legitimacy of its claims to influence. A large home market makes a state more influential in internal market negotiations, military 
capabilities enable a state to exercise leadership in the EU's foreign and security policy, and population size grants voice in an EU claiming to be a democratic community.

According to the interviewees, national executives representing structurally advantaged states are allowed greater latitude in the negotiations. Jean-Claude Juncker explains: "If you are representing a medium-sized country, you can never say 'Denmark thinks....' You can only say 'I would submit to your considerations, if not....' Those who are speaking for greater member states, by opening their mouth and by referring to their national flag, they are immediately indicating that, behind their words, you have to accept size and demography. 'La France pense que...' and 'Deutschland denkt...,' that is something different.” Göran Persson, former prime minister of Sweden, points to a parallel dynamic: “If you are the prime minister of a country with five to ten million people, you simply cannot monopolize twenty percent of the time devoted to the conclusions, it is not possible.” Interviewees further testify that large member states may get away with tactics that are otherwise are considered inappropriate, such as exploiting the inadequate preparation of an issue to push through their own proposal, or launching entirely new initiatives at the negotiation table.

Whereas the dominant expectation before the eastern enlargement was that the large member states would suffer in influence, because of the accession of twelve small or mediumsized countries, the testimonies of European Council participants suggest otherwise. Paradoxically, the dominance of the large member states may instead have been reinforced, as issues that previously were settled in the formal plenary sessions increasingly are resolved in informal and minilateral negotiations, managed by the Presidency and with participation by those parties most essential for reaching an agreement that subsequently can be extended to the broader membership. In practice, those parties have tended to be the EU's large member states, sometimes joined by small or medium-sized states with particular stakes in the issue. 
One top-level official in the Council Secretariat observes: "There is a danger for the small and medium-sized countries in the new development. If you as President want to come to a deal, who will you consult? The main actors - Germany, France, the UK.” Similarly, one small state representative concludes: "It is obviously the bigger countries [who are benefiting from a move from multilateral to bilateral negotiations]. Their relative weight is always bigger in any bilateral discussion.”

The centrality of aggregate structural power for European Council negotiations is a constant theme in the interviews. Yet so are the exceptions to this pattern. Even in this intergovernmental forum, strong states do not always prevail and weak states do not always suffer. Every single interviewee points to additional dimensions of power and can recite cases that support a more comprehensive picture of bargaining power in the European Council. The remainder of this paper will be devoted to these other dimensions of bargaining power, of which the first is a more specified interpretation of when, where, and how differences in state properties matter.

\section{Issue-specific power}

The notion of issue-specific power has developed into the favored explanation in modern negotiation analysis for patterns of bargaining success that diverge from those predicted by the distribution of aggregate resources. According to this line of argument, resources and capabilities may not be deployed with equal effectiveness in all issues and relationships. Rather, it is the power balance in the issue-specific relationship that determines bargaining outcomes (even if aggregate resources may shape the issue-specific power balance). This helps to explain paradoxes of power in international negotiation, such as when structurally disadvantaged states nevertheless prevail in negotiations with structurally advantaged states, 
owing to superior issue-specific power (Odell 1980; Bacharach and Lawler 1981; Habeeb 1988).

Issue-specific power is defined by a state's resources in a particular issue, its commitment to this issue, and its alternatives to a negotiated agreement on this issue. The issue-specific nature of resources entails that a state’s bargaining power in economic affairs, for instance, will not be decided by its military capability, territory, or population, but by its market power and GDP (Habeeb 1988). The commitment of a state on a particular issue, sometimes referred to as its preference intensity, willpower, resolve, attention or stake, matters since states that care deeply about an issue will be more willing to devote scarce resources, negotiate with greater care, stay longer at the negotiation table, and have higher aspirations, than states that are less committed (Mesquita and Stokman 1994; Hopmann 1998; Bailer 2004). Finally, states with good alternatives to negotiated agreements will be less likely to compromise and more likely to shape the final outcome, than states desperately in need of a joint agreement (Fisher and Ury 1981; Lax and Sebenius 1986; Moravcsik 1998).

European Council participants testify that issue-specific aspects of power are prominent in negotiations. The relative weight of the member states shifts depending on the issue, as a product of the resources they can deploy, national commitments to particular causes, and the attractiveness of the status quo. However, it should be noted that the empirical establishment of such power is made difficult by overlaps between issue-specific and aggregate structural power, giving rise to observational equivalence. For instance, it is difficult to determine whether the influence of German, French, and British executives in negotiations on the internal market or the EU's long-term budget is a product of these countries' superior economic strength alone or their general advantages in terms of aggregate structural power. Still, it is possible to isolate a number of expressions of issue-specific power 
in European Council negotiations, by focusing on cases where aggregate and issue-specific resources diverge.

A first expression of issue-specific power is the tendency of large member states not to wield equal power on all issues. European Council participants most frequently point to the restricted role of Germany in the EU's foreign and security policy, compared to France and the UK. As the EU's greatest military powers, in possession of both extensive conventional capabilities and nuclear weapons, France and the UK speak with considerable authority on issues of security policy. Even if Germany in recent years has become more willing to invest resources in military capabilities for international operations, its influence in the European Council on issues of foreign and security policy is not on par with that of France and the UK. Another often mentioned example is Italy’s loss of bargaining power on economic issues, despite a sizeable GDP, because of long-running budget deficits and a growing government debt.

A second expression of issue-specific power noted by European Council participants is the tendency of small or medium-sized states to "punch above their weight" - to exercise more power on specific issues than a mere assessment of their aggregate structural resources would lead us to expect. Small and medium-sized states with specific regional interests often succeed in shaping the EU's policy toward these areas, owing to extensive experience in dealing with the region, as well as great commitment to the development of EU policy vis-àvis the region. Prominent examples are the engagement of Belgium in Central Africa, the Netherlands in Indonesia, Spain in the Mediterranean, and the Nordics in the Baltic. European Council participants further testify to specific small-state influence on issues where these countries present strong ambitions, extensive knowledge, and national policies that may be exported to the European level, for instance, the Nordic states on employment policy and environmental policy. Finally, the combination of a strong commitment and an attractive 
status quo alternative has strengthened the hand of certain small or medium-sized member states on specific dossiers, for instance, Greece on issues relating to Turkey and Luxembourg on issues pertaining to financial services.

\section{Institutional sources of power}

Negotiations in the European Council take place in a specific institutional setting. How and to what extent do the properties of this institutional setting shape bargaining power and outcomes in the European Council? Drawing on a combination of negotiation theory and institutional theory, I identify two institutional factors with implications for bargaining power in the European Council: the veto and the chairmanship.

The power of the veto

The most central institutional feature of any negotiation is the decision rule governing the adoption of joint agreements. Unanimity requires that all parties give their consent, or at least do not actively block an agreement. Majority voting entails that only a large subset of all parties needs to be on board for an agreement to be reached. Where decisions are taken through majority voting, as in the EU's general legislative process, differentiation of voting power based on population or GDP grants those states that already enjoy structural power advantages in the formal decision-making system as well. By contrast, where decisions require unanimity, as in the European Council, this works to mediate or offset the impact of structural power differentials, by giving all parties equal formal right to block proposals through the veto. 
Studies of international negotiations find that veto provisions strengthen the bargaining position of parties or coalitions that do not enjoy structural power, and constitute one of the principal sources of influence for weak states in competition with the strong (Zartman 1971; Habeeb 1988; Hampston with Hart 1995, 32). Furthermore, existing research establishes that unanimity tends to generate processes of consensual decision-making, where recalcitrant parties are bought off through side-payments and favors are exchanged through package deals. The states expected to benefit the most from unanimity as decision principle are therefore those most pleased with the status quo, that is, those who would lose the least if an agreement could not be found (Scharpf 1997; Meunier 2000; Moravcsik 1998).

European Council participants testify that the actual wielding of the veto is a relatively rare occurrence in summit negotiations, but very effective when used. When national executives walk into the European Council, they know they will have to agree, and if a state has strong objections on an issue, it will often prevail. As Erkki Tuomioja, former Finnish minister of foreign affairs, states: “At the end of the day, you can block. Moving forward at the European Council depends on consensus. In general there is still this kind of understanding, although no one talks about the Luxembourg compromise any longer...If a country’s vital national interests are at stake, this is respected.” One EU ambassador underlines the same point in colorful language: "If you have the guts, you can use the veto with great effect. You’ve got everybody by their balls.”

Why, then, is the veto not wielded more frequently? European Council participants point to four reasons. First, the veto is a measure of last resort, and skillful negotiators should be able to convey the importance they attach to an issue and secure others' respect, without actually using the weapon. Göran Persson goes as far as saying: "The veto is only an asset as long as it is not used.” Second, it needs to be generally understood that the issues in question are of truly vital national importance for the state concerned, or else the use of the veto will 
have reputation repercussions. Third and related, the veto is only effective if it is not wielded too frequently. The use of the veto carries a political cost in terms of credibility. As David O’Sullivan, former secretary general of the Commission, notes: “They cannot threaten to block all the time. Even if they might have three issues they would want to block, they only have one card each to play.” Jean-Claude Juncker explains this logic in greater detail, and emphasizes the political gains of abstaining from the veto:

If a prime minister, sitting with his colleagues, is threatening with a veto time after time, he loses all kinds of influence. It is seen as a sign of weakness, because if you give the impression that you do not have free hands at home, you cannot really develop an influence in the European Council. But, if from time to time, you step away from a well-known national position, saying 'OK, I will take it, but I will have great difficulties at home,' then you gradually build up a kind of aura that this is not only about words and lip-service, but that you are willing to undergo some difficulties at home.

Finally, the veto does not put an end to the political process. Conflicts must be solved and proposals adopted. As Finland’s president, Tarja Halonen, underlines: “[The veto may be used] when you really need it and you have a plan what to do after that. Because saying no, you do not stop the process. You just take a time-out.”

European Council participants testify that the veto is used more frequently on some issues than on others, and more effectively by some member states than by others. As regards issues, they specifically point to negotiations on the EU's long-term budgets and to bargaining over treaty reform. These are issues with such general political and economic implications that they bring vital national interests to the fore and legitimate the wielding of the veto. As regards member states, they frequently mention Spain as a country whose representatives have been very skillful in exploiting the power of the veto, especially in negotiations over the EU’s long-term budgets. As one chief executive states: "Spain is very good at having results. [They achieve results by] being tough, being very tough. They are not impossible - you 
always know that there is a price to buy them. You can be impossible, so that the others know that you will say forever no. [But] if you negotiate a good result, [the Spanish] will say yes.” Furthermore, differences in structural power are perceived to affect the legitimacy of wielding the veto. According to one prime minister, it is a simple reality of politics that "Luxembourg can issue a veto once in a decade, and Britain once per week.” By the same token, the veto of large member states is perceived to carry more weight than that of the small or medium-sized, according to David O’Sullivan: “The veto of Cyprus is not the same as the veto of Germany.”

The power of the chair

Research on multilateral bargaining suggests that the chairmanship of international decision bodies constitutes a power platform, enabling the actors in control of this office to shape the outcomes of negotiations (Tallberg 2006; but also Hampson with Hart 1995; Odell 2005). Negotiation chairs are typically granted the responsibility to manage the agenda, broker agreements, and represent the decision body vis-à-vis third parties. In these functions, negotiation chairs benefit from privileged access to a set of power resources, notably asymmetric information and procedural control. Bilateral encounters at which governments offer negotiation chairs information about national resistance points provides chairmen with unique information about state preferences. Furthermore, international secretariats at the chairman's special disposal endow negotiation chairs with expert information about the technical subject matter of the negotiations. The procedural power of negotiation chairs consists of control over decisions on the sequence of negotiations, the frequency of negotiation sessions, the format of negotiations, and the method of negotiation. Moreover, as managers of individual negotiation sessions, chairmen open and conclude meetings, structure 
the meeting agenda, allot the right to speak, direct voting procedures, and summarize the results. The legitimacy of the office, the trust acquired in previous negotiations, and the capacity of chairmen to persuade others through the better argument may constitute additional resources.

With very few exceptions, European Council participants underline the significance of the Presidency as a resource for the incumbent. It is notable that representatives of small and medium-sized states tend to rank access to the Presidency as the most important source of power, particulary for themselves, since they cannot rely on advantages in structural power. As Finland’s Erkki Tuomioja asserts: “The Presidency is always in a strong position. Even small country Presidencies, if they are successful and do their homework, can have a lot of influence. The Presidency is always number one.” Similarly, former Swedish foreign minister Lena Hjelm-Wallén emphasizes: “The chairmanship is the most important power resource you are holding the reins,” whereas Gunnar Lund, former Swedish EU ambassador, stresses: "It is obvious. The Presidency grants considerable influence, even for a small country. You are managing the entire process.”

More specifically, European Council participants point to the setting of the agenda and the engineering of compromises as the functions through which Presidencies exert influence. It is the Presidency that carries the responsibility, and enjoys the privilege, of preparing the agenda of European Council meetings. Part of the agenda of individual meetings tends to be pre-determined, as an effect of the European Council's growing tendency to pre-program forthcoming meetings in order to achieve greater policy continuity. In addition, the European Council generally devotes part of its meetings to EU or international matters that require the attention of the heads of government. Yet, even with these constraints, the Presidency can affect the agenda and the outcome of meetings by contributing its own pet issues to the agenda, attributing varying weight to the items on the agenda, and keeping 
certain issues away from the agenda. It is frequently emphasized by European Council participants that the greatest influence over the agenda is exerted in the preparatory phase, when the Presidency structures and delimits the agenda, rather than in the meetings per se. Sweden’s Göran Persson offers the following reflection:

As the chairman of a meeting, you are controlling the agenda. It is those who realize the potential to set the agenda that affect the development [of EU policy]. Then you need not dominate the meeting, but it is the issues that you yourself have put up on the agenda that are discussed. If you do not control the agenda as chairman - and there have been such Presidencies - then nothing will come of it. It has to be prepared, and this is a truth that applies to local associations and the European Council alike. If you are to have any chance of governing the meeting, then you must decide the contents of the agenda.

Since several issues that require the European Council’s attention are "hard cases," where the member states have been unable to reach agreement at lower levels, brokerage constitutes a central function for Presidencies. Typically, heads of government rely on two institutionalized practices for sounding out state concerns and devising acceptable compromise agreements - the tour des capitales and the confessional. The President of the European Council either travels to or receives all other heads of government in the weeks preceding the summit. The format of the bilateral encounter enables heads of government to share information about their bottom lines with the Presidency, thus improving the chances of summit agreements on contentious issues. Confessionals serve the same purpose during the course of actual meetings. According to European Council members, both practices grant the Presidency a politically privileged position in the engineering of agreements.

\section{Individual Sources of Power}


Negotiations in the European Council are conducted by individuals who represent their states. How and to what extent do differences in individual attributes affect the bargaining power of the national executives? Drawing on theories of negotiation and leadership, I discuss in this section the potential impact of two categories of individual attributes: personal authority and expertise. European Council participants testify that variation within the group in the shape and distribution of individual attributes affects the bargaining power of the respective states. Whereas some individuals strengthen the bargaining position of the states they represent, owing to personal authority and high levels of expertise, other individuals constitute liabilities for the states they represent. A prominent explanation for this impact of individual attributes is the format of negotiations in European Council, where the heads of government largely operate on their own, beyond the immediate control of national civil servants.

\section{Personal authority}

The importance of individual personality traits, experiences, and authority is an issue that has received extensive attention in the study of international negotiations and foreign policy decision-making. One line of inquiry specifically addresses how the cognitive structures of leaders affect behavior in bargaining (Jönsson 1990), whereas another strand of analysis explores the influence of leadership style on foreign policy decision-making (e.g., Hermann et et al. 2001). The influential notion of negotiations as two-level games, involving both domestic and international bargaining, generates the expectation that heads of government will enjoy a certain level of autonomy, to the effect that personalities and personal preferences may impact on negotiation outcomes (Putnam 1988; Evans, Jacobson, and Putnam 1993). Finally, students of international negotiation propose that specific individuals may succeed in shaping how other participants perceive of problems and solutions through ideas and visions, 
as well as through authority and trust earned in previous interaction (Young 1991; Risse 2000).

The importance of personal relations and personal authority is a recurring theme in the participants' own assessments of influence in the European Council. In particular, they underline the differences between individuals in terms of personal respect and trust, which are seen as attributes to be won and earned, rather than given by birth or appointment. One implication is that seniority in the club and earlier performance are perceived to matter. As Philippe Schoutheete (2006, 46), long-serving EU ambassador of Belgium, testifies: "Because participants are relatively few in number and personal relations important, the balance of power in the European Council is influenced by seniority. Newcomers will not be able to pull their full weight at first meetings. Heads of government of smaller member states can expect to exert more influence after several years of being present, particularly after they led a successful presidency.”

This analysis is shared by those leaders of small and medium-sized countries who most frequently are mentioned as examples of growing personal influence over time, next to Belgium’s Guy Verhofstadt and the Netherlands’ Wim Kok. Jean-Claude Juncker, presently the longest serving head of government, stresses the importance of "personal experience, personal relations with leaders of other countries, [and] the volume of confidence you have worked up. If you are there for a longer time, you become a reference point for others, mainly for the newcomers, and they are inspired by what you are saying.” Similarly, Göran Persson, who attended the European Council for a full decade, admits: "My own position in the European Council is obviously a product of having been there long. I have been able to welcome many, say goodbye to many, and still remain myself.”

Inquiries into the importance of personalities invariably lead to comparisons between individual leaders. The observations by European Council participants are remarkably similar 
with respect to the role of five heads of state or government during the last decade: Jacques Chirac, Gerhard Schröder, Tony Blair, Silvio Berlusconi, and Jean-Claude Juncker. Whereas Chirac and Juncker are perceived to have strengthened the bargaining hand of their countries because of their personal qualities, Schröder and Blair have neither contributed positively nor negatively, whereas Berlusconi unanimously is presented as a liability for his country. Chirac is described as a political animal who is very clever and persistent, somewhat arrogant, capable of instilling fear in others through his temper, and almost always very influential. Schröder, by contrast, is portrayed as surprisingly silent, without an interest in the political game, often detached from the debate, and therefore dependent on others' automatic respect for German interests, even if he was listened to on those occasions when he spoke up. Blair's influence is typically seen as less extensive than his spin-doctors make it seem, and with the important exceptions of the Lisbon process and transatlantic issues, "he is not really in the game, although destroying the games of others.” Berlusconi is consistently portrayed as a maverick leader with a limited interest in EU issues, irratic negotiation behavior, and a selfassumed role as the comedian of the club. Juncker, finally, is described as the head of government who by himself commands the greatest respect and authority, because of his long time in the European Council, his extreme experience and competence, his capacity to put European interests before national (of which there are few), and his networking abilities and close relationship with especially German and French leaders. As one head of government put it: ”How many times do you need to multiply Juncker's weight because of his personal and human attributes? Juncker probably weighs more than countries with twelve to fourteen million inhabitants.”

\section{Expertise}


The advantages of possessing expertise and information in bargaining are widely acknowledged. Multilateral negotiations are characterized by high levels of complexity and uncertainty, because of the large number of parties, proposals, and preferences (Winham 1977; Zartman 1994; Hampson with Hart 1995). As a result, negotiators seldom have perfect knowledge of the many technical issues on the agenda, the legal procedures available, and the preferences of other actors. However, some may be better informed than others, and those parties that possess superior expertise are also better positioned to identify potential agreements and shape outcomes in their own favor (Young 1991; Tallberg 2006). It is common in the literature to distinguish between three alternative forms of expertise: content expertise, process expertise, and preference information (Wall and Lynn 1993; Beach 2005). Content expertise refers to technical knowledge of the issues under negotiation. Process expertise refers to knowledge of the institutional framework of negotiations, including legal provisions and procedures. Preference information, finally, refers to knowledge of other parties’ interests and domestic political constraints.

European Council participants frequently highlight the importance of personal expertise in summit negotiations, and testify to varying levels of content, process, and preference expertise among the participants. Even if the heads of government ought to be well briefed when they arrive, there are sometimes glaring gaps in knowledge, with implications for the negotiations. One particular feature of European Council meetings merits special attention in this context, namely the deliberate separation of the national executives from the civil servants, in order to create an atmosphere more conducive to concessions and compromises. An important side-effect of this arrangement is that the national executives are largely on their own, and that differences in the level of personal expertise therefore matter more than in the Council of Ministers or in other international negotiations, where legions of specialists normally accompany the chief negotiator. 
Content expertise is deemed very important, indeed a prerequisite for influence, by European Council participants. Even if all parties profit from mastering the technical details of the dossiers, representatives of small and medium-sized states emphasize that issue expertise is particularly pivotal for them, since they cannot rely on structural power, and that they therefore have greater incentives to be well informed. In this vein, Erkki Tuomioja observes: "Smaller countries tend to do their homework better. They cannot afford not to be knowledgeable about the issues.” Jean-Claude Juncker makes a similar observation: “The knowledge of dossiers is essential. I have to say that my experience is that those representing smaller and medium-sized countries, they have the better knowledge of the dossier, because they have less people to prepare it, they have less speaking notes and transport mechanisms than the others. And if you have a broader knowledge than your colleagues, then you can give indications, you are able to introduce nuances, you can draw up broader perspectives, taking pieces from other meetings or other portfolios.”

In the European Council, it is the Council Secretariat's specific task to be wellversed in all the procedural and legal aspects of decision-making. Yet the Secretariat's presence does not eliminate differences in process expertise and their implications for bargaining power. Some heads of government have developed considerable knowledge of the EU's institutional system and its procedural idiosynchracies, whereas others face significant shortages. Philippe de Schotheete (2006, 39) notes that not all national executives understand the formal procedures applicable in the European Council. One long-serving head of government confirms these deficits in process expertise, and points specifically to the prime ministers from the new member states, who only recently gained seats in the European Council, suffer from high turn-over rates, and seldom have been portfolio ministers and therefore are unfamiliar with the EU's institutions. Typical gaps in knowledge include the Commission's monopoly on initiative in the first pillar and the European Parliament's equal 
status to the Council of Ministers under the co-decision procedure - basic features of the EU political system.

Information about other parties’ preferences is a prerequisite for building coalitions and negotiating agreements in the European Council. Generally, national executives perceive themselves to be well-briefed on the positions of the others. Yet there is a difference between knowing what the position is, and understanding why this particular position is taken. According to European Council participants, there is sometimes a lack of understanding of the domestic political debate in other member states that renders it difficult to arrive at compromise agreements acceptable to all parties. As one experienced prime minister concludes: "The real problem of the European Council is that the majority of the members...do not have the time or do not take the time to be totally informed in a way that, leaving behind their national interests, they can develop compromise formulas. --- What people say is seldom unreasonable, it is simply political.”

\section{Conclusion}

The central message of this paper is that bargaining power in the European Council is polymorphic. Testimonies from a broad sample of European Council participants strongly suggest that bargaining power in this forum cannot be reduced to either a matter of formal equality or a question of great power dominance. Rather, the relative power of national executives is a product of the structural capabilities of the member states they represent, their access to institutional resources in the European Council, and their own personal qualities as negotiators. Yet not all forms of bargaining power are equally prominent in shaping negotiation outcomes. European Council participants testify that differences in structural 
power are most fundamental, with the effect that France, Germany, and the UK most often set the parameters of summit negotiations. Even if structural capabilities rarely are deployed directly in the negotiation process, they impact indirectly, by defining a state's range of options, the resources it can commit to an issue, and the legitimacy of its claim to shape joint decisions. The institutional and individual dimensions of power tend to be of secondary importance and mainly mediate the impact of structural power asymmetry. These results suggest that the European Council offers greater lee-way for power politics than any other EU institution. Whereas the impact of structural power differentials in the EU's general legislative process is softened by the involvement of the supranational institutions, the European Council offers more limited institutional protection to small and medium-sized member states. Somewhat paradoxically, the enlargement of the EU appears to have strengthened these qualities of the European Council, by moving negotiations away from the plenary meetings of the summits and into informal and minilateral sessions dominated by the large member states.

This paper does not offer the final word on bargaining power in the European Council. Rather, it constitutes a first step toward a more advanced understanding of bargaining in the European Council, laying the ground for future research by identifying and explicating multiple sources of power in summit negotiations. Yet, even with this more limited ambition, the paper speaks to prominent lacunae in research on EU politics and international negotiation.

First, it opens up a new area of research on the politics of summitry, in the EU and elsewhere. Existing literature on the European Council is typically atheoretical, refraining from integrating insights from the general political science literature on negotiation and decision-making. Furthermore, it tends to be heavily centered on the historical evolution of the European Council and its contribution to European integration, and silent on the issue of bargaining dynamics within. This paper demonstrates that general negotiation theory is a 
highly effective instrument for untangling alternative sources of power in the European Council. Moreover, it contributes to advancing the research on summitry politics in general a subject that so far has received exceedingly limited attention (for a rare contribution, see Putnam and Bayne 1987).

Second, the paper points to the limits of presenting dominant IR theories as competing explanations of state influence in international cooperation. Rather, this inventory of bargaining power in the European Council underlines the complementarity of resources privileged by alternative theories of power in international relations: the importance of structural power (realism), the power of the veto (rational choice institutionalism), and the power of persuasion (constructivism).

Third and finally, the paper engages in the kind of analytical groundwork that is called for in the IR literature on power. As David Baldwin $(2002,186)$ emphasizes in a recent review: "Instead of focusing on how a given power distribution affects regime formation or war initiation, international relations scholars need to devote more attention to questions like 'Who has power with respect to which other actors, on which issues?' 'By what means is this power exercised?' and 'What resources allow states to exercise this power?’” 


\section{Appendix: Interviews}

The title or function of the interviewee is given as it was held at the time of the interview, and in the capacity that he or she is relevant for the project.

Frank Belfrage, former Permanent Representative to the EU, Sweden. November 17, 2005. Bernard Bot, Minister of Foreign Affairs, the Netherlands, May 15, 2005.

Ingvar Carlsson, former Prime Minister, Sweden. September 8, 2004.

Robert Cooper, Director General of DG E, General Secretariat of the Council. February 3, 2005.

Lars Danielsson, State Secretary, Sweden. September 8, 2004.

Kim Darroch, Head of the European Secretariat, Cabinet Office, the United Kingdom. November 29, 2006.

Jacques Delors, former President of the European Commission. December 21, 2006.

David Galloway, Head of the Private Office of the Assistant Secretary General, General

Secretariat of the Council. November 3, 2004.

Valéry Giscard d’Estaing, former President, France. December 7, 2005.

Felipe Gonzáles, former Prime Minister, Spain. May 17, 2005.

Tarja Halonen, President, Finland. May 27, 2005.

Lena Hjelm-Wallén, former Minister of Foreign Affairs, Sweden. October 28, 2004.

Jean-Claude Juncker, Prime Minister, Luxembourg. December 8, 2005.

John Kerr, former Permanent Representative to the EU, the United Kingdom. November 28, 2006.

Neil Kinnock, former European Commissioner, the United Kingdom. November 29, 2006. 
Claas D. Knoop, Minister at the Permanent Representation, Germany. November 5, 2004.

Wim Kok, former Prime Minister, the Netherlands. May 15, 2005.

Erkki Liikanen, former European Commissioner, Finland. May 27, 2005.

Gunnar Lund, former Permanent Representative to the EU, Sweden. September 7, 2004.

John Major, former Prime Minister, the United Kingdom. December 1, 2006.

Guy Milton, Adviser, General Secretariat of the Council, February 3, 2005.

David O’Sullivan, Secretary General, European Commission. February 2, 2005.

Göran Persson, Prime Minister, Sweden. January 25, 2005.

Sven-Olof Petersson, Permanent Representative to the EU, Sweden. September 24, 2004.

Michel Petite, Director General of the Legal Service, European Commission. November 3, 2004.

Jean-Claude Piris, Director General of the Legal Service, General Secretariat of the Council. February 3, 2005.

Paolo Ponzano, Director of the Task Force on the Future of the EU and Institutional

Questions, European Commission. November 5, 2004.

Poul Nyrup Rasmussen, former Prime Minister, Denmark. November 11, 2005.

Javier Solana, Secretary General of the General Secretariat of the Council. December 12, 2006.

Erkki Tuomioja, Minister of Foreign Affairs, Finland. May 27, 2005.

Hubert Védrine, former Minister of Foreign Affairs, France. November 17, 2005.

Jerôme Vignon, former Director of the Forward Studies Unit, European Commission. February 3, 2005.

Stephen Wall, former Permanent Representative to the EU, the United Kingdom. November 30, 2006. 


\section{References}

Bacharach, Samuel B. and Edward J. Lawler (1981) Bargaining: Power, Tactics and Outcomes. San Fransisco, Cal.: Jossey-Bass.

Bailer, Stefanie (2004) Bargaining Success in the European Union. European Union Politics 5 (1): 99-123.

Baldwin, David A. (2002) Power and International Relations. In Handbook of International Relations, edited by Walter Carlsnaes, Thomas Risse, and Beth A. Simmons, 177-191. London: Sage.

Beach, Derek (2005) The Dynamics of European Integration: Why and When EU Institutions Matter. Houndmills: Palgrave Macmillan.

Bulmer, Simon och Wolfgang Wessels (1987) The European Council: Decision-Making in European Politics. Houndmills: MacMillan.

Donat, Marcell von (1987) Das ist der Gipfel! Die EG-Regierungschefs unter sich. BadenBaden: Nomos Verlagsgesellschaft.

Evans, Peter B., Harold K. Jacobson, and Robert D. Putnam (eds.) (1993) Double-Edged Diplomacy: International Bargaining and Domestic Politics. Berkeley, Cal.: University of California Press.

Fisher, Roger and William Ury (1981) Getting to Yes: Negotiating Agreement Without Giving In. Boston: Houghton Mifflin.

Grant, Charles (2002) Restoring Leadership to the European Council. London: Centre for European Reform.

Habeeb, William Mark (1988) Power and Tactics in International Negotiation: How Weak Nations Bargain with Strong Nations. Baltimore, Md.: The Johns Hopkins University Press. 
Hampson, Fen Osler with Michael Hart (1995) Multilateral Negotiations. Lessons from Arms Control, Trade, and the Environment. Baltimore, Md.: The Johns Hopkins University Press.

Hayes-Renshaw, Fiona and Helen Wallace (2006) The Council of Ministers. $2^{\text {nd }}$ edition. Basingstoke: Palgrave Macmillan.

Hermann, Margaret G., Thomas Preston, Baghat Korany, and Timothy M. Shaw (2001) Who Leads Matters: The Effects of Powerful Individuals. International Studies Review 3 (2): 83-131.

Hopmann, P. Terrence (1996) The Negotiation Process and the Resolution of International Conflicts. Columbia, S.C.: University of South Carolina Press.

Johnston, Mary Troy (1994) The European Council: Gatekeeper of the European Community (Boulder, Colo.: Westview Press).

Jönsson, Christer (1990) Communication in International Bargaining. London: Pinter.

Lax, David A. and James K. Sebenius (1986) The Manager as Negotiator. New York, N.Y.: The Free press.

Ludlow, Peter (2002) The Laeken Council. Brussels: EuroComment.

Ludlow, Peter (2004) The Making of the new Europe: The European Councils in Brussels and Copenhagen 2002. Brussels: EuroComment.

Mesquita, Bruce Bueno de and Frans N. Stokman (eds.) (1994) European Community Decision-Making: Models, Applications and Comparisons. New Haven, Conn.: Yale University Press.

Meunier, Sophie (2000) What Single Voice? European Institutions and EU-US Trade Negotiations. International Organization, 54 (1): 103-135.

Moravcsik, Andrew (1998) The Choice for Europe: Social Purpose and State Power from Messina to Maastricht. Ithaca, N.Y.: Cornell University Press. 
Morgenthau, Hans (1948) Politics Among Nations: The Struggle for Power and Peace. New York: Knopf.

Odell, John S. (1980) Latin American Trade Negotiations with the United States. International Organization 34 (2): 207-228.

Odell, John (2005) Chairing a WTO Negotiation. Journal of International Economic Law 8 (2): 425-448.

Putnam, Robert D. (1988) Diplomacy and Domestic Politics: The Logic of Two-Level Games. International Organization 42: 427-60.

Putnam, Robert D. and Nicholas Bayne (1987) Hanging Together: Cooperation and Conflict in the Seven-Power Summits. London: Sage.

Risse, Thomas (2000) “Let’s Argue!”: Communicative Action in World Politics. International Organization 54 (1): 1-39.

Scharpf, Fritz W. (1997) Games Real Actors Play. Boulder, Colo.: Westview Press. Schoutheete, Philippe de (2006) The European Council. In The Institutions of the European Union, edited by John Peterson and Michael Shackleton, 37-59. Oxford: Oxford University Press.

Schoutheete, Philippe de and Helen Wallace (2002) The European Council. Paris: Notre Europe.

Tallberg, Jonas (2006) Leadership and Negotiation in the European Union. Cambridge: Cambridge University Press.

Taulègne, Béatrice (1993) Le Conseil Européen. Paris: Presses Universitaires de France. Wall, James A. and Ann Lynn (1993) Mediation: A Current Overview. Journal of Conflict Resolution 37 (1): 160-194.

Waltz, Kenneth N. (1979) Theory of International Politics. New York: McGraw-Hill. Werts, Jan (1992) The European Council. Amsterdam: North-Holland. 
Westlake, Martin and David Galloway with Toon Digneffe (2004) The Council of the European Union. $3^{\text {rd }}$ edition. London: John Harper Publishing.

Winham, Gilbert R. (1977) Negotiation as a Management Process. World Politics 30 (1): 87114.

Young, Oran R. (1991) Political Leadership and Regime Formation: On the Development of Institutions in International Society. International Organization 45 (3): 281-308.

Zartman, I. William (1971) The Politics of Trade Negotiations between Africa and the European Economic Community. Princeton: Princeton University Press.

Zartman, I. William (1994) Two’s Company and More’s a Crowd: The Complexities of Multilateral Negotiation. In International Multilateral Negotiations, edited by I. William Zartman, 1-10. San Francisco, Cal.: Jossey-Bass. 